\title{
Demografsko starenje na hrvatskim otocima
}

DOI: $10.11567 /$ met.29.2.2

UDK: 314(497.5)(210-7)

Izvorni znanstveni rad

Primljeno:15.6.2013.

Prihvaćeno:12.10.2013.

\author{
Ivo Nejašmić \\ Učiteljski fakultet, Zagreb \\ ivo.nejasmic@ufzg.hr
}

Otok bez čovika je ništa, obična stina u moru!

(Šoltanin, 76 g.)

\section{SAŽETAK}

U radu se analiziraju promjene u sastavu stanovništva hrvatskog otočja prema dobi, upozorava na stupanj ostarjelosti stanovništva, daje prostorna diferencijacija procesa te predočuje perspektiva starenja na razini naselja. Tipizacija stupnja ostarjelosti stanovništva temelji se na bodovnoj vrijednosti i ima sedam tipova. Ukupna otočna populacija u 2011. godini pripada tipu 5 - vrlo duboka starost. Gotovo polovina naseljskog skupa (od ukupno 303 naselja) zahvaćena je najvišim stupnjevima ostarjelosti (tipovi 6 i 7). Utvrđeno je da će četvrtina otočnih naselja postati »mrtva sela« u doglednoj budućnosti; najviše ih je na malim otocima, ali i u unutrašnjosti većih otoka. To su sela koja u svakom pogledu propadaju, u kojima vene i gasi se oblik života kakav poznajemo. Sadašnji ostarjeli seljaci uglavnom su i njihovi posljednji stanovnici. Sve govori da demografska obnova otoka nije moguća sa snagama in situ. Za uspješnu organizaciju života na otocima, malim i velikim, važno je uspostaviti ravnotežu između potreba i mogućnosti, a činjenica je da u tome postoji trajni nerazmjer, koji je posebice dubok na malim otocima. U prevladavanju nepovoljnih demografskih tendencija nužan je senzibilan i selektivan pristup. Stoga je u osmišljavanju strategije razvoja nužno poštovati posebnosti pojedinih otočnih skupina i otoka. Do rješenja problema treba doći djelovanjem lokalne i šire zajednice u sinergiji s relevantnim stručnim i znanstvenim ustanovama. Ako se pak ne nađu rješenja ili mjere ne dadu rezultata, ako se otoke prepusti stihiji depopulacije i senilizacije, dio otočja postat će pustoš. To bi s obzirom na vrijednost tog prostora, čije su bogatstvo prije svega ljudi, bio nedopustivi civilizacijski nazadak.

KLJUČNE RIJEČI: hrvatski otoci, starenje stanovništva, demografska perspektiva, posljedice starenja 


\section{UVOD}

Hrvatsko otočje obuhvaća gotovo sve otoke istočne obale Jadrana i drugo je po veličini (tj. broju otoka) otočje Sredozemlja. Ukupno je u hrvatskom dijelu Jadrana 1246 otoka, otočića, hridi i grebena (79 otoka, 525 otočića, 642 hridi i grebena) (Duplančić Leder, Ujević i Čala, 2004). To je 96,1\% od ukupnog broja otoka, hridi i grebena u Jadranskome moru. Površina je hrvatskog otočja oko $3300 \mathrm{~km}^{2}$, što je 5,8\% površine kopnenog dijela državnog teritorija.

Posebnost otoka njihova je izoliranost, odnosno odvojenost morem od kopna i drugih otoka, što stvara otočne mikrokozmose i specifične ekosustave. Otok je »...čitav mali svijet, planet sa svojom vlastitom gravitacijom « (Božanić, 1996: 66). Izoliranost utječe na ukupni društveno-gospodarski razvoj, uvjete života te oblikovanje karakterističnih sociopsiholoških tipova otočana i njihovih zajednica (Lajić, 1992; Friganović, 2001). U suvremenim uvjetima prostorne povezanosti i društveno-gospodarske međuzavisnosti stupanj izoliranosti pojedinih otoka ovisi o udaljenosti otoka od obale i postojećim prometnim vezama s urbanim središtima na obali (Stiperski, Malić i Kovačević, 2001; Faričić, 2012).

U svojoj tisućljetnoj naseljenosti istočnojadranski su otoci bili »vrata povijesti i civilizacije«, da bi u novije doba, posebice tijekom 20. stoljeća, došli na rub društvenog interesa. Retrogradni procesi koji se odvijaju na otocima posve su suprotni stvarnoj i potencijalnoj vrijednosti promatranog prostora. Podaci demografske statistike i rezultati istraživanja kažu da je riječ o snažnoj depopulaciji, procesu nastalom početkom 20. stoljeća, a zahuktalom poslije Drugoga svjetskog rata. Godine 1900. na otocima je živjelo 167.000 stanovnika ili 5,3\% od ukupnog stanovništva (odnosi se na stanovništvo koje je živjelo na današnjem teritoriju Republike Hrvatske), 1953. bilo ih je 151.331 ili 3,9\%, a 2011. popisano je 124.955 stanovnika ili 2,9\% ukupnog stanovništva. Gustoća naseljenosti (37,9 stanovnika na $\left.\mathrm{km}^{2}\right)$ niža je nego na ostalim sredozemnim otočnim skupinama.

Danas je otočje, uz brdsko-planinske krajeve, populacijski najslabije područje Hrvatske. Još se davnih šezdesetih godina 20. stoljeća moglo reći »... da otoci, osobito oni manji, demografski odumiru« (Friganović, 1962: 37). Na otocima, posebice onima koji se nisu pravodobno uključili u suvremeno turističko privređivanje, odlazak mladeži poprimio je obilježje posvemašnjeg egzodusa (Lajić, 1995a; Podgorelec, 1998). Činjenica da je iseljavanje glavni čimbenik depopulacije sama po sebi upućuje na okljaštrenu dobnu strukturu stanovništva te na veću ili manju neravnotežu prema spolu (Ne- 
jašmić, 1991a). To je neizbježna posljedica selektivnosti emigracije. Isto tako, jako iseljavanje implicira sužavanje fertilnih skupina, slabljenje vitalnog potencijala i pad (bio)reproduktivne moći (Wertheimer-Baletić, 1999). Na taj način populacijska dinamika sve više postaje logična posljedica deformiranoga dobnog sastava i procesa demografskog starenja (Nejašmić, 2005).

Razvojem suvremenog turizma i porastom društvene svijesti o zaštiti okoliša otočje ponovno izbija u prvi plan kao jedan od najvrednijih dijelova nacionalnog prostora. Sukladno tome poraslo je i zanimanje društva za otočnu problematiku, a posebnu pozornost stručne i šire javnosti zaokupljaju demografska stanja i procesi. No još je uvijek malo radova u domaćoj literaturi koji podrobnije razmatraju demografsko starenje na otocima. Obično se toj problematici pristupa u sklopu analize općih demografskih promjena na hrvatskim otocima (Mikačić, 1987; Nejašmić, 1991b; Smoljanović, Smoljanović i Nejašmić, 1999; Friganović, 2001). Demografsko starenje razmatra se i u sklopu analize demografskoga (biološkog) sastava (Nejašmić, 1992) ili se obrađuju pojedine implikacije tog procesa (Podgorelec, 2008; Šimunović, 2010). Pojedini radovi bave se značajkama demografskog starenja pojedinih otoka ili skupine otoka u okviru razmatranja općih sociodemografskih značajki (Wertheimer-Baletić, 1979; Faričić i Magaš, 2004; Lajić, 2006; Nejašmić i Mišetić, 2006; Graovac-Matassi, 2010).

Temeljem znanstvene analize, obradom podataka prikupljenih iz statističkih i drugih sekundarnih izvora te upotrebom teorijske i empirijske literature $\mathrm{u}$ radu se analiziraju promjene $\mathrm{u}$ sastavu stanovništva otočja prema dobi, razmatraju značajke demografskog starenja, upućuje na stupanj ostarjelosti stanovništva i daje prostorna diferencijacija osnovnih obilježja tog procesa (do razine naselja), predočuje perspektiva razmatranog procesa i pokušava dati odgovor na pitanje kako ublažiti posljedice starenja stanovništvai usporiti ga.

Svrha je rada da kroz utvrđivanje stupnja ostarjelosti stanovništva pojedinih otoka, kao i relevantnih otočnih skupina, upozori na njihovu demografsku perspektivu te da egzaktnim pokazateljima potkrijepi znanstvenu spoznaju o populacijskom razvoju tog dijela nacionalnog prostora. Težište je na podrobnijem razmatranju sadašnjeg stanja, temeljenom na podacima posljednjeg popisa stanovništva 2011.

\section{METODOLOŠKE NAPOMENE}

Zbog boljeg razumijevanja predočene građe nužno je ukratko dati neke važnije napomene. Ovisno o cilju istraživanja i prostornoj definiciji njegova 
predmeta otočje je moguće istraživati od razine pojedinih otočnih naselja, otoka, otočnih podskupina i otočnih regionalnih skupina, zatim prema kriteriju veličine, udaljenosti od kopna itd. (Lajić i Nejašmić, 1994).

1. Prema kriterijima postojanja jednog naselja, 67 je naseljenih otoka, a prema kriteriju živog naselja, što znači da na otoku doista cijele godine živi stanovništvo, broj se spušta na 47. Otočni naseljski skup čine samostalna naselja prema službenoj statistici upotrijebljenoj u popisu 2011. (Popis 2011.). No za potrebe ove analize izostavljeno je osam naselja bez stalnih stanovnika te tri svjetioničarske naseobine: Palagruža, Glavat i Sušac. Dakle otočni naseljski skup čine 303 naselja. Prosječni je broj stanovnika 412, a najveće naselje ima 6090 stanovnika.

2. Hrvatski naseljeni jadranski otoci razvrstani su u četiri otočne skupine: ${ }^{1}$

a) kvarnerski otoci: Krk, Cres, Lošinj i Rab te skupina manjih otoka

b) sjevernodalmatinski otoci: u ovu skupinu ušao je otok Pag, ${ }^{2}$ te svi otoci od Silbe do Krapnja

c) srednjodalmatinski otoci: od Drvenika malog do Hvara i Visa

d) južnodalmatinski otoci: od Korčule i Lastova do Koločepa.

3. Otočni i naseljski skup razvrstan je u podskupine za koje se moglo pretpostaviti da će iskazati različite vrijednosti razmatranih demografskih značajki. To su:

a) veliki otoci (veći od $\left.110 \mathrm{~km}^{2}\right):^{3}$ Krk, Cres, Brač, Hvar, Pag, Korčula i Dugi otok; srednji otoci (od 51 do 110 km²): Mljet, Vis, Rab, Lošinj, Pašman, Šolta i Ugljan; mali otoci (od 20 do $50 \mathrm{~km}^{2}$ ): Lastovo, Kornat, Čiovo, Olib, Vir i Molat; vrlo mali otoci (manji od $\left.20 \mathrm{~km}^{2}\right): 27$ naseljenih otoka i otočića

b) unutarnji (priobalni) otoci: Krk, Rab, Pag, Vir, Ugljan, Pašman, Vrgada, Murter, Prvić (kod Šibenika), Zlarin, Krapanj, Drvenik mali, Drvenik veli, Čiovo, Šolta, Brač, Šipan, Koločep i Lopud; vanjski otoci: svi ostali naseljeni otoci

U regionalizaciji hrvatskih otoka postoji i peta skupina, zapadnoistarski otoci, no ovdje je ispuštena jer na tim otocima nema naselja kao aglomeracije stalnih stanovnika.

2 Po klasičnoj regionalizaciji, Pag je dio kvarnerskog otočja (usp. Rubić, 1952), ali suvremeni geografski radovi uglavnom ga svrstavaju u srednjodalmatinsku skupinu (usp. Faričić, 2012).

3 U svjetskoj i domaćoj literaturi prisutne su različite tipologije otoka s obzirom na njihovu površinu i broj stanovnika. Neki autori malim otocima smatraju one koji imaju površinu manju od $10.000 \mathrm{~km}^{2}$ i manje od 500.000 stanovnika (Royle, 2001). Po tome su svi hrvatski otoci (i većina sredozemnih) zapravo mali otoci. Očito za hrvatske otoke treba primijeniti drugi kriterij, koji je prilagođen njihovoj veličini i broju stanovnika. Polazeći od ukupnog broja stanovnika, I. Lajić i R. Mišetić (2006) razvrstavaju hrvatske otoke u četiri skupine: veliki, s više od 3000 stanovnika, srednji, od 251 do 3000 stanovnika, mali, od 51 do 250 stanovnika, i iznimno mali, na kojima živi do 50 stanovnika. 
c) naselja - središta općina/gradova (46 naselja); ostala naselja (257 naselja).

\section{DEMOGRAFSKO STARENJE -RAZVOJ I SADAŠNJE STANJE}

\section{Promjene u sastavu stanovništva prema dobi}

Sastav prema dobi po svojim je društveno-gospodarskim implikacijama jedna od najvažnijih značajki stanovništva. Odražava biodinamiku i potencijalnu vitalnost stanovništva nekog područja. »Iz nje se vidi prošlost, čita sadašnjost i nazire budućnost kretanja stanovništva« (Friganović, 1990: 111). Promjene u dobnom sastavu stanovništva hrvatskih otoka sadržavaju dva usporedna globalna demografska procesa: smanjivanje udjela mladih uz istovremeno povećavanje udjela starog stanovništva. Riječ je o starenju stanovništva ili demografskom starenju, pojmu pod kojim se u literaturi najčešće razumijeva povećanje udjela stanovništva starog 60 i više ili 65 i više godina u ukupnom stanovništvu (Wertheimer-Baletić, 1999). ${ }^{4}$ To je, zapravo, skupni demografski izraz biološkog starenja pojedinaca.

Otočno stanovništvo najvjerojatnije je već u vrijeme prvoga poslijeratnog popisa 1948. bilo zahvaćeno procesom demografskog starenja. No za tu popisnu godinu nije bilo moguće izdvojiti podatke za sve naseljene otoke jer o sastavu stanovništva prema dobi postoje podaci samo za kotare i gradove. Podaci za 1953. jasno pokazuju da je starenje stanovništva već ojačalo. Te je godine bilo 15,7\% stanovništva u dobi 60 i više godina, odnosno 11,3\% u dobi 65 i više godina (tab. 1). ${ }^{5} \mathrm{U}$ sljedećim popisnim razdobljima starenje je uzelo maha, i to kao integralni dio procesa demografske tranzicije (u njegovoj središnjoj i kasnoj podetapi), a posebice dolazi do izražaja u posttranzicijskoj etapi.

Zbog sve duljega životnog vijeka u razvijenim je zemljama pomaknuta (statistička) granica između zrele i stare skupine; starim se smatra stanovništvo od 65 i više godina. Tome se sve više priklanja i dokumentacija Ujedinjenih naroda.

5 Kada udio osoba starih 60 i više godina dosegne 12\%, odnosno 8\% starih 65 i više godina, smatra se da je stanovništvo neke zemlje ili područja počelo starjeti (Wertheimer-Baletić, 1999). 
Tablica1. Sastav prema dobi stanovništva hrvatskih otoka po petogodišnjim dobnim skupinama* 1953., 1991. i 2011. i pokazatelj promjene broja stanovnika 1991. - 2011.**

Table 1. Age structure of the Croatian islands' population by five-year age groups*,1953, 1991 and 2011, and the indicator of changes in the population number 1991-2011**

\begin{tabular}{|c|c|c|c|c|c|}
\hline \multirow{3}{*}{$\begin{array}{l}\text { Dobne } \\
\text { skupine }\end{array}$} & \multicolumn{4}{|c|}{ Godina } & \multirow{3}{*}{$\begin{array}{c}\text { Indeks promjene } \\
\text { udjela 2011./91. }\end{array}$} \\
\hline & \multirow{2}{*}{$\begin{array}{c}1953 . \\
\%\end{array}$} & \multirow{2}{*}{$\begin{array}{c}1991 . \\
\%\end{array}$} & \multicolumn{2}{|c|}{2011.} & \\
\hline & & & $\%$ & broj & \\
\hline $0-4$ & 9,61 & 5,96 & 4,38 & 5478 & 73,5 \\
\hline $5-9$ & 8,15 & 6,46 & 4,02 & 5020 & 62,2 \\
\hline $10-14$ & 8,55 & 6,38 & 4,35 & 5438 & 68,2 \\
\hline $15-19$ & 8,98 & 6,10 & 5,04 & 6296 & 82,6 \\
\hline $20-24$ & 8,29 & 6,16 & 5,66 & 7079 & 91,9 \\
\hline $25-29$ & 6,75 & 6,75 & 6,19 & 7736 & 97,7 \\
\hline $30-34$ & 6,00 & 7,46 & 6,05 & 7555 & 81,1 \\
\hline $35-39$ & 4,28 & 7,41 & 5,67 & 7089 & 76,5 \\
\hline $40-44$ & 6,95 & 7,26 & 5,88 & 7343 & 81,0 \\
\hline $45-49$ & 6,21 & 4,46 & 6,62 & 8272 & 148,4 \\
\hline $50-54$ & 5,51 & 5,88 & 7,56 & 9453 & 128,6 \\
\hline $55-59$ & 4,99 & 6,53 & 7,96 & 9942 & 121,9 \\
\hline $60-64$ & 4,47 & 5,87 & 8,53 & 10.661 & 145,3 \\
\hline $65-69^{* * *}$ & 11,26 & 5,51 & 5,53 & 6916 & 100,4 \\
\hline $70-74$ & & 3,33 & 6,08 & 7598 & 182,6 \\
\hline $75-79 * * *$ & & 8,48 & 5,25 & 6561 & $* * * 123,6$ \\
\hline $80-84$ & & & 3,17 & 3956 & \\
\hline $85-89$ & & & 1,57 & 1958 & \\
\hline $90-94$ & & & 0,39 & 485 & \\
\hline 95 i više & & & 0,10 & 119 & \\
\hline Ukupno & 100,00 & 100,00 & 100,00 & 124.955 & - \\
\hline
\end{tabular}

* Za 1953. i 1991. bez stanovništva nepoznate dobi; u popisu 2011. nepoznata dob ionako nije posebno iskazana.

** Razlike u metodologiji popisa, posebice 1991. i 2011., donekle utječu na točnost usporedbe (više o tome u bilješci 6).

*** Za godine 1953. i 1991. dostupni su podaci za petogodišnje dobne skupine; za 1953. najstariji je otvoreni razred 65 i više godina, a za 1991. godinu 75 i više.

Izvor: Popis stanovništva 1953., Starost, pismenost i narodnost, knjiga XI, Savezni zavod za statistiku, Beograd, 1960.; Popis stanovništva, kućanstava i stanova 1991., Stanovništvo 
po spolu i starosti, općinski tablogrami po naseljima, Državni zavod za statistiku, Zagreb, 1992.; Popis stanovništva, kućanstava i stanova 2011., Stanovništvo prema starosti $i$ spolu, Državni zavod za statistiku, Zagreb, http://www.dzs.hr

Usporedba podataka triju popisa pokazuje da stanovništvo hrvatskih otoka obilježavaju brzo starenje i visoki stupanj ostarjelosti (tablica 1). ${ }^{6}$ Razvidno je smanjenje udjela mladih, s posebno jakim smanjenjem udjela najmlađih skupina, a s druge strane povećanje udjela starih stanovnika, posebice onih najstarije dobi (slika 1). Usporedba 1953. i 2011. pokazuje da se udio najmlađih kohorti $(0-14)$ prepolovio, a udio starih 65 i više udvostručio (tablica 1)! Godine 2011. udjel mladih 0 - 14 godina iznosio je 12,8\% (odgovarajući je udjel za Hrvatsku 15,2\%), mladih 0 - 19 godina 17,8\% (Hrvatska 20,9\%), udjel starih 60 i više godina 30,6\% (Hrvatska 24,1\%), a udjel starih 65 i više godina 22,1\% (Hrvatska 17,7\%).

Posebno su instruktivni podaci o promjeni udjela pojedinih funkcionalnih dobnih kontingenata u ukupnom stanovništvu 1991. - 2011. ${ }^{7}$ Upućuju na nastavak trendova starenja ukupnog stanovništva, kao i na intenzitet promjene $u$ dobnim kontingentima ( $\mathrm{zv}$. parcijalno starenje). Indeks promjene udjela stanovnika hrvatskih otoka 1991. - 2011. prema pojedinim dobnim skupinama jest sljedeći: 0-14, 68,1; 0-19, 71,5; 15-39, 84,4; 40-64, 122,$0 ; 15-64,102,0 ; 60$ i više, 131,9; 65 i više, 127,$7 ; 75$ i više, $123,6$.

6 Metodologija popisa stanovništva 2011. razlikuje se od metodologije popisa 1953. i 1991. Popis 1953. proveden je po koncepciji »stalnog stanovništva« (de iure). Popis 1991. proveden je po istoj koncepciji, a ostat će zabilježeno da je obuhvatio veliki kontingent »osoba na privremenom radu u inozemstvu«. Tako je otok Olib 1981. imao tri »inozemca«, a 1991. čak 571. Kako je u vezi s otocima riječ uglavnom o "prekomorskom iseljeništvu«, taj je kontingent značajno zamaglio stvarno stanje (»revitalizacija na papiru«). S druge strane, u stalno stanovništvo nisu ulazile »osobe koje su u Hrvatskoj boravile godinu i duže» (a takve su osobe 2011. uvrštene u stalno stanovništvo). U popisu 2011. prihvaćen je koncept »uobičajenog mjesta stanovanja « (place of usual residence) s vremenskim ograničenjem odsutnosti do dvanaest mjeseci, a prvi put uvodi se namjera odsutnosti/prisutnosti kao dodatni kriterij za uključivanje osoba u ukupno stanovništvo ili isključivanje iz njega. Razlike u metodologiji »administrativno « utječu na usporedivost podataka, ali se može reći da utjecaj na strukturna obilježja nije tolik kao u slučaju promjene broja stanovnika.

7 U distribuciji za 1991. zanimljiva je kohorta 45 - 49 godina. Brojila je 5500 osoba s udjelom od 4,46\%. Sve upućuje na »krnju generaciju« koja je bila izložena smanjenju nataliteta tijekom Drugoga svjetskog rata. No ta je skupina 1953. bila u dobi 7 - 11 godina i brojila više od 12.000 osoba, što govori da su djelovali i drugi čimbenici. Uzimajući u obzir i mortalitet, očigledno je na drastično smanjenje te kohorte utjecalo iseljavanje. U vrijeme najjačega otočnog egzodusa ta je skupina bila u »optimalnoj mobilnoj« dobi! 
Slika 1. Dobni sastav stanovništva hrvatskih otoka po petogodišnjim dobnim skupinama 1991. i 2011.

Figure 1. Age structure of the Croatian islands' population by five-year age groups, 1991 and 2011

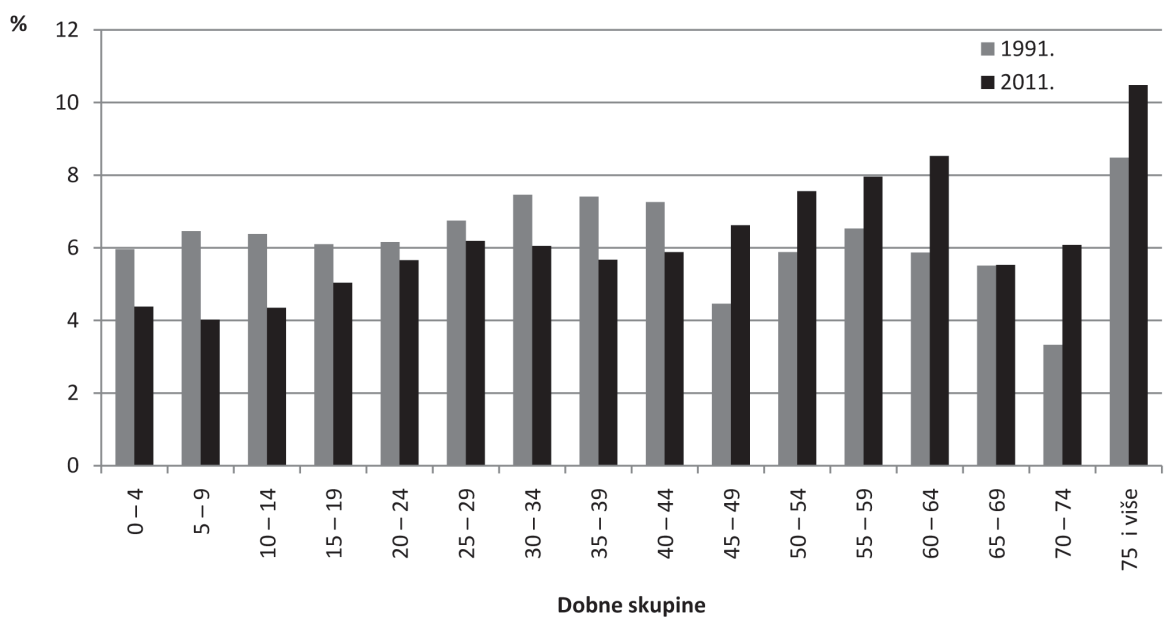

Prosječna dob otočnog stanovništva iznosi 44,6 godina, a ukupnog stanovništva Hrvatske 41,7 (2011.). Usporedba s ukupnom populacijom pokazuje da je na otocima stanje nepovoljnije, ali ne koliko bi se očekivalo s obzirom na to da su oni dugo izloženi jakom iseljavanju i depopulaciji. Razloge tome valja tražiti donekle u stabiliziranju demografskih prilika u dijelu otočja (otoci poput Brača, Lošinja i Raba ponderiraju ukupno kretanje), ali je "približavanje distribucija« još više rezultat jačanja nepovoljnih demografskih tendencija u ukupnoj populaciji. Hrvatska sve više poprima obličje svojih demografski okljaštrenih područja!

Prosječna dob stanovništva svih otočnih skupina vrlo je visoka: kvarnerski otoci 43,2 godine; sjevernodalmatinski 47,1; srednjodalmatinski 44,4; južnodalmatinski 43,5 ; veliki otoci 44,0 ; srednji 44,7 ; mali 44,4 ; vrlo mali 49,0; unutarnji otoci 44,6; vanjski 44,5. Prosječna dob stanovništva naselja - središta općina/gradova jest 43,4 godine, a skupine ostalih naselja 46,4 (Popis 2011., izračunao autor). Razlike među skupinama nisu velike, ali su znakovite. Najveća je razlika u skupini otoka razvrstanih prema veličini. U skupini malih otoka prosječna je dob stanovništva za pet godina viša nego u skupini velikih. Budući da je u sjevernodalmatinskoj skupini najveći udio malih i raštrkanih otoka, logično je bilo očekivati i najvišu prosječnu dob stanovništva. Zanimljivo je da nema razlike između unutarnjih i vanjskih otoka. Razlika u prosječnoj dobi stanovništva središnjih otočnih naselja 
(središta općina/gradova) i ostalih naselja iznosi svega tri godine. Podatak prema kojem je prosječna dob stanovništva viša u skupini »ostala naselja « sukladan je nalazima nekih prijašnjih istraživanja (usp. Friganović, 1980-81; Mišetić, 2006).

Predočeni sastav stanovništva hrvatskih otoka prema dobi posljedica je djelovanja kolopleta čimbenika. Generiran je prije svega zaostajanjem u društveno-gospodarskom razvoju te izravno povezan sa stoljetnim iseljavanjem (Foretić, 1969; Lajić, 1989; Nejašmić, 1991a; Defilippis, 1997). Koncem pedesetih godina 20. stoljeća kao značajan čimbenik javlja se i negativna prirodna promjena, koja je rezultat odgođenog učinka iseljavanja, gubitaka u svjetskim ratovima te opće tranzicije nataliteta (Mikačić, 1987; Lajić, 1995b; Nejašmić, 1997). Dugotrajnije smanjivanje rodnosti dovodi do kontrakcije mladih dobnih skupina i posljedično do povećanja udjela starog stanovništva. Smanjenje smrtnosti također utječe na demografsko starenje - razumije se, ne smanjenje bilo koje specifične stope smrtnosti prema dobi. Smatra se da tek snižavanje smrtnosti u dobi preko trideset godina utječe na demografsko starenje (Wertheimer-Baletić, 2009). Smanjivanje smrtnosti znači produljenje ljudskog vijeka, tj. očekivanog trajanja života, a to izravno utječe na povećanje staračkoga kontingenta. Navedeni čimbenici podrobno su obrađeni u znanstvenoj literaturi (dio relevantnih bibliografskih jedinica navodi se i u ovom radu), pa je suvišno posebno ih razmatrati.

\section{Stupanj ostarjelosti}

Teškoće demografske analize »malih populacija« ogledaju se u tome što i najmanje apsolutne promjene izazivaju osjetne relativne promjene (Lajić i Nejašmić, 1994). Na otocima je prisutna inverzija dobne "piramide« (na nekim malim otocima uopće nema mladog stanovništva). Stoga nije preporučljivo upotrebljavati uobičajene analitičke pokazatelje kao što je indeks starosti (može imati toliko ekstremne vrijednosti da je praktično beskoristan). Budući da je kod otoka riječ o raširenom i odmaklom procesu demografskog starenja, vrednovanje treba prilagoditi toj činjenici te zapravo tipizirati stupanj ostarjelosti otočnog stanovništva. To je posebice važno kada se uspoređuje više prostornih jedinica. Dakle umjesto tipizacije temeljene na pukoj kombinaciji »mladih« $\mathrm{i}$ »starih « dobnih skupina bodovan je posebice svaki parametar da bi se zbrajanjem tih vrijednosti dobio bodovni pokazatelj ostarjelosti stanovništva $\left(b_{s}\right) .{ }^{8}$ Tipizacija koja se temelji na bodov-

8 To je preinačeni model M. Klemenčića (1990); posebice je pogodan način »mjerenja« stupnja demografskog starenja za područja i populacije u kojima je mali broj mladih ili ih uopće nema. Postupak bodovanja jest sljedeći: udio mladih ( 0 - 19 godina) boduje se u rasponu od 0,0 do 30,0 bodova, dakle veći udio mladih boduje se većim brojem bodova. Udio starih 
noj vrijednosti ima sedam tipova (stupnjeva) ostarjelosti, a svaki tip ima i odgovarajuće opisno obilježje (tablica 2). Razvidno je da populacija s većim brojem bodova ima manji stupanj ostarjelosti.

Tablica 2. Tipizacija ostarjelosti utemeljena na bodovnoj vrijednosti

Table 2. Typing of aging based on scores

\begin{tabular}{ccc}
\hline $\begin{array}{c}\text { Bodovni pokazatelj ostarjelosti } \\
\left(\mathbf{b}_{\mathbf{s}} \mathbf{)}\right.\end{array}$ & Tip & Obilježje: \\
\hline $90,5-100,0$ & $\mathbf{1}$ & na pragu starenja \\
\hline $84,5-90,0$ & $\mathbf{2}$ & starenje \\
\hline $73,0-84,0$ & $\mathbf{3}$ & starost \\
\hline $65,5-72,5$ & $\mathbf{4}$ & duboka starost \\
\hline $50,5-65,0$ & $\mathbf{5}$ & vrlo duboka starost \\
\hline $30,5-50,0$ & $\mathbf{6}$ & izrazito duboka starost \\
\hline $0,0-30,0$ & $\mathbf{7}$ & krajnje duboka starost
\end{tabular}

Prema: Nejašmić, 2005: 191

Ukupna je otočna populacija bodovana s 57,5 bodova, što znači da u 2011. pripada tipu 5 - vrlo duboka starost (tablica 3). Dva desetljeća prije sa 72,5 bodova bila je u ranoj fazi tipa 4 (drugim riječima, otočna populacija bila je tek »zakoračila « $\mathrm{u}$ duboku starost). Trend ubrzanog starenja stanovništva hrvatskih otoka očigledan je. Usporedba sa stanjem 1991. pokazuje da je stanovništvo svih otočnih i naseljskih skupina prešlo u viši »razred « ostarjelosti. Pritom je dio skupina preskočio jedan stupanj, odnosno prešao iz tipa 3 u tip 5 - vrlo duboka starost (kvarnerski otoci, srednjodalmatinski, južnodalmatinski, veliki i srednji otoci). Razlike u stupnju ostarjelosti stanovništva među pojedinim skupinama otoka i otočnih naselja nisu velike, ali ipak znakovito potvrđuju već uočenu prostornu diferencijalnost razmatranog procesa. Najizrazitija je ostarjelost stanovništva na sjevernodalmatinskim otocima, koji pripadaju tipu 6 - izrazito duboka starost, a istom tipu pripada skupina vrlo malih otoka. ${ }^{9}$ Kad je o veličini otoka riječ, usporedba bodovnih

(60 i više) boduje se u rasponu od 0,0 do 70,0 bodova, ali tako da veći udio starih donosi manji broj bodova (obratno nego kod bodovanja udjela mladih); vrijednost udjela (\%) zaokružuje se na $0,5 \%$ (npr. $25,4 \%$ na $25,5 \%$ ). Budući da veći udio mladih, a manji udio starih donosi veći konačni broj bodova, može se ustvrditi da populacija s većim brojem bodova ima manji stupanj ostarjelosti (više o tome: Nejašmić, 2005).

9 Mali otoci bilježe veću bodovnu vrijednost od očekivane. Takvo stanje ponderira stanovništvo (polu)otoka Čiova s udjelom od gotovo $60 \%$ u ukupnoj populaciji skupine, a ima $b_{s}$ 61,0 (tablica 4). Isti je slučaj sa skupinom vrlo malih otoka, u kojoj stanovništvo (polu)otoka Murtera čini $54 \%$ ukupne populacije skupine, a ima $\mathrm{b}_{\mathrm{s}} 57,5$ ! 
vrijednosti 1991. i 2011. pokazuje da se smanjuju razlike u stupnju ostarjelosti stanovništva između velikih i malih otoka. To se može objasniti time što na velikim otocima još uvijek postoji određeni kontingent mladog stanovništva. On je po definiciji jače podložan promjenama (zapravo smanjenju zbog iseljavanja ili nedovoljnog obnavljanja natalitetom) te tako utječe na starenje ukupnog stanovništva. Populacija vrlo malih otoka u stanju je pak da mladih gotovo i nema. To znači da na starenje utječu mahom promjene u staračkom kontingentu, a to ovisi o pomicanju zrelih dobnih skupina u staračku dob i djelovanju globalnog čimbenika - produljenja ljudskog vijeka.

Znakovito je da nema razlike u stupnju ostarjelosti stanovništva između unutarnjih i vanjskih otoka. Očigledno je da ni bolja prometna dostupnost unutarnjih otoka (neki su i povezani mostom s kontinentalnim kopnom) nije mogla umanjiti silinu demografskog starenja. Nadalje, razlika između skupine naselja - središta općina/gradova i ostalih naselja manja je od očekivane. No valja imati u vidu da je malo današnjih općinskih središta koja su desetljećima imala upravnu funkciju. Središta takvih starih općina jesu: Krk, Mali Lošinj, Rab, Pag, Supetar, Hvar, Vis, Lastovo i Korčula. S izuzetkom Lastova riječ je o razmjerno velikom naseljima. U novoj upravnoj podjeli (46 općina) prevladavaju mala općinska središta, a neka su i vrlo mala (Dobrinj, središte istoimene općine na Krku, ima 109 stanovnika; Babino Polje, središte općine Mljet, ima ih 270). Razumije se da u takvoj upravnonaseljskoj strukturi nije ni realno očekivati veće razlike u stupnju ostarjelosti stanovništva, a ni u nekim drugim demografskim pojavama i procesima.

Tablica3. Temeljni pokazatelji ostarjelosti stanovništva pojedinih skupina otoka i otočnih naselja 2011. i usporedba bodovnih vrijednosti s 1991. godinom

Table 3. Basic indicators of population ageing in certain groups of islands and island settlements in 2001, and comparison of scoring values with the year 1991

\begin{tabular}{|c|c|c|c|c|c|c|}
\hline \multirow{2}{*}{$\begin{array}{l}\text { Skupina otoka ili } \\
\text { naselja }\end{array}$} & \multirow{2}{*}{$\begin{array}{c}\text { Bodovi } \\
\left(\mathbf{b}_{\mathrm{s}}\right) \\
1991 .\end{array}$} & \multicolumn{2}{|c|}{ Udjel (\%) } & \multirow{2}{*}{$\begin{array}{c}\text { Bodovi } \\
\left(\mathbf{b}_{\mathrm{s}}\right) \\
2011 .\end{array}$} & \multicolumn{2}{|c|}{ Stupanj ostarjelosti 2011.} \\
\hline & & $\begin{array}{l}\text { mladih } \\
(0-19)\end{array}$ & $\begin{array}{c}\text { starih } \\
\left(60^{+}\right)\end{array}$ & & tip & obilježje \\
\hline Kvarnerski & 77,0 & 18,2 & 26,8 & 61,0 & 5 & vrlo duboka starost \\
\hline Sjevernodalmatinski & 65,5 & 16,1 & 36,2 & 50,0 & 6 & izrazito duboka starost \\
\hline Srednjodalmatinski & 73,0 & 17,8 & 31,1 & 57,0 & 5 & vrlo duboka starost \\
\hline Južnodalmatinski & 73,0 & 19,9 & 28,8 & 61,0 & 5 & vrlo duboka starost \\
\hline Veliki otoci & 73,5 & 18,3 & 29,4 & 59,0 & 5 & vrlo duboka starost \\
\hline
\end{tabular}




\begin{tabular}{|c|c|c|c|c|c|c|}
\hline \multirow{2}{*}{$\begin{array}{l}\text { Skupina otoka ili } \\
\text { naselja }\end{array}$} & \multirow{2}{*}{$\begin{array}{c}\text { Bodovi } \\
\left(b_{s}\right) \\
1991\end{array}$} & \multicolumn{2}{|c|}{ Udjel (\%) } & \multirow{2}{*}{$\begin{array}{c}\text { Bodovi } \\
\left(b_{s}\right) \\
2011 .\end{array}$} & \multicolumn{2}{|c|}{ Stupanj ostarjelosti 2011.} \\
\hline & & $\begin{array}{c}\text { mladih } \\
(0-19)\end{array}$ & $\begin{array}{c}\text { starih } \\
\left(60^{+}\right)\end{array}$ & & tip & obilježje \\
\hline Srednji otoci & 73,5 & 17,4 & 30,3 & 57,0 & 5 & vrlo duboka starost \\
\hline Mali otoci & 65,5 & 17,9 & 31,6 & 56,5 & 5 & vrlo duboka starost \\
\hline Vrlo mali otoci & 55,3 & 14,8 & 39,8 & 45,0 & 6 & izrazito duboka starost \\
\hline Unutarnji otoci & 72,5 & 17,6 & 30,9 & 56,5 & 5 & vrlo duboka starost \\
\hline Vanjski otoci & 71,0 & 18,1 & 30,2 & 58,0 & 5 & vrlo duboka starost \\
\hline Središta općina* & 77,5 & 18,8 & 28,2 & 61,0 & 5 & vrlo duboka starost \\
\hline Ostala naselja & 68,0 & 16,3 & 34,4 & 52,0 & 5 & vrlo duboka starost \\
\hline Otočje - ukupno & 72,5 & 17,8 & 30,6 & 57,5 & 5 & vrlo duboka starost \\
\hline
\end{tabular}

* Retrospekcija se odnosi na naselja koja su bila središta općina u vrijeme popisa stanovništva 2011.

Izvor: Popis 1991., Popis 2011., izračunao autor

Male razlike u stupnju ostarjelosti stanovništva, odnosno činjenica da sve predočene otočne i naseljske skupine nalazimo u samo dva tipa ostarjelosti (većinu u samo jednome), jasno pokazuju da je demografsko starenje ušlo u kasnu razvojnu fazu. Proces traje već dugo, pa je nakon početne selektivnosti (prvo su bili zahvaćeni mali, vanjski otoci) i zrele faze, koju je obilježila prostorna diferenciranost, ušao $\mathrm{u}$ fazu homogenizacije ostarjelosti, barem na razini otočnih i naseljskih skupina.

Kakva je slika na razini pojedinih otoka? Još je nepovoljnija nego što pokazuju skupni podaci. Od ukupno 43 otoka (ukupno ih je 47, ali za pet nije računat stupanj ostarjelosti zbog malog broja stanovnika, manje od dvadeset) ni u jednom slučaju stanovništvo ne pripada tipovima 1, 2 i 3 ostarjelosti (tablica 4). Samo je stanovništvo otoka Lošinja u tipu 4 - duboka starost. Ujedno je to jedini otok čije stanovništvo ima stupanj ostarjelosti kao i ukupno stanovništvo Hrvatske $\left(b_{\mathrm{s}}=67,0\right)$. Stanovništvo sedamnaest otoka nalazi se u tipu 5 - vrlo duboka starost. To je šarolika skupina u kojoj su najveći otoci (površinom i populacijom) nekoliko otoka iz skupine vrlo malih otoka (priobalni otoci Murter, Šipan i Koločep), kao i pravi pučinski otoci (Vis i Lastovo). Stanovništvo osam otoka pripada tipu 6 - izrazito duboka starost; $\mathrm{u}$ toj su skupini jedan veliki otok (Dugi otok), dva srednja i pet vrlo malih otoka. U tipu 7 - krajnje duboka starost našlo se stanovništvo sedamnaest otoka, od čega su dva mala (Olib i Molat), a ostali pripadaju skupini vrlo malih otoka. Još je jednom potvrđena gorka činjenica da je stanovništvo malih otoka, posebice vrlo malih i raštrkanih, najjače pogođeno demografskim starenjem. Na mnogima udio starih 60 i više godina prelazi dvije trećine: 
Molat 79,2\%, Žirje 74,8\%, Rivanj 74,2\%, Rava 71,8\%, Drvenik veli 70,0\%, Zverinac 69,8\%, Drvenik mali 66,7\% i Sestrunj 66,7\%.

Tablica 4. Redoslijed hrvatskih otoka prema vrijednosti bodovnog pokazatelja ostarjelosti stanovništva $\left(b_{s}\right) 2011$.

Table 4. Order of Croatian islands according to the value of scoring indicators of population ageing $\left(b_{s}\right)$ in 2011

\begin{tabular}{|c|c|c|c|c|c|c|c|}
\hline $\begin{array}{l}\text { Red. } \\
\text { broj }\end{array}$ & Otok & $\mathbf{b}_{\mathrm{s}}$ & Tip & $\begin{array}{l}\text { Red. } \\
\text { broj }\end{array}$ & Otok & $\mathbf{b}_{\mathrm{s}}$ & Tip \\
\hline 1. & Lošinj & 67,0 & 4 & 25. & Šolta & 36,5 & 6 \\
\hline 2. & Korčula & 62,5 & 5 & 26. & Silba & 32,0 & 6 \\
\hline 3. & $\mathrm{Rab}$ & 61,5 & 5 & 27. & Vrgada & 30,0 & 7 \\
\hline 4. & Čiovo & 61,0 & 5 & 28. & Prvić (Ši) & 29,0 & 7 \\
\hline 5. & Lastovo & 60,5 & 5 & 29. & Ošljak & 28,5 & 7 \\
\hline 6. & Cres & 60,0 & 5 & 30. & Zlarin & 27,5 & 7 \\
\hline 7. & Krk & 59,5 & 5 & 31. & Iž & 22,5 & 7 \\
\hline 8. & Brač & 58,0 & 5 & 32. & Kaprije & 19,5 & 7 \\
\hline 9. & Hvar & 58,0 & 5 & 33. & Premuda & 14,0 & 7 \\
\hline 10. & Murter & 57,5 & 5 & 34. & Olib & 13,0 & 7 \\
\hline 11. & Pag & 57,0 & 5 & 35. & Sestrunj & 7,5 & 7 \\
\hline 12. & Šipan & 55,5 & 5 & 36. & Rava & 5,0 & 7 \\
\hline 13. & Pašman & 54,5 & 5 & 37. & Ist & 4,5 & 7 \\
\hline 14. & Vis & 54,0 & 5 & 38. & Drvenik mali & 3,5 & 7 \\
\hline 15. & Vir & 52,0 & 5 & 39. & Drvenik veli & 2,5 & 7 \\
\hline 16. & Koločep & 51,5 & 5 & 40. & Žirje & 2,0 & 7 \\
\hline 17. & Mljet & 50,5 & 5 & 41. & Molat & 1,5 & 7 \\
\hline 18. & Krapanj & 50,5 & 5 & 42. & Zverinac* $^{*}$ & 0,0 & 7 \\
\hline 19. & Lopud & 49,5 & 6 & 43. & Rivanj* $^{*}$ & 0,0 & 7 \\
\hline 20. & Ugljan & 48,0 & 6 & \multicolumn{2}{|c|}{ Vele Srakane (3)** } & & \\
\hline 21. & Ilovik & 45,5 & 6 & \multicolumn{2}{|c|}{ Male Srakane (2) } & & \\
\hline 22. & Susak & 44,5 & 6 & \multicolumn{2}{|c|}{ Kornat (19) } & & \\
\hline 23. & Dugi otok & 39,0 & 6 & \multicolumn{2}{|c|}{ Biševo(15) } & & \\
\hline 24. & Unije & 38,5 & 6 & & JE - ukupno & 57,5 & 5 \\
\hline
\end{tabular}

* Bodovna je vrijednost 0,0; na oba je otoka udio mladih (0 - 19) $0 \%$, a udio starih (60+): Zverinac 69,8\% i Rivanj 74,2\% (ili u oba slučaja 0 bodova; vidjeti bilješku 8).

** Četiri otoka imaju tako mali broj stanovnika (broj u zagradi) da nema nikakva smisla izračunavati bodovni pokazatelj ostarjelosti, a ni druge pokazatelje.

Izvor: Popis 2011., izračunao autor 
Podrobnu sliku demografskog starenja na hrvatskim otocima pružaju analitički podaci na razini naselja (prilog 1). Iz bodovnog vrednovanja ostarjelosti stanovništva izuzeta su naselja s manje od dvadeset stanovnika (ukupno ih je 36) jer je često u dobnim skupinama koje ulaze u izračun svega nekoliko osoba. No valja istaknuti da mahom u tim naseljima prevladavaju stari stanovnici. S obzirom na malu populacijsku masu to ih svrstava u demografski krajnje ugrožena naselja.

Pokazalo se da je samo jedno naselje u tipu 1 - na pragu starenja, Skrivena Luka na Lastovu. ${ }^{10}$ Dva su naselja u tipu 2 - starenje, Zaklopatica na Lastovu i Sveti Ivan na Krku. U tipu 3 - starost nalazi se 14 naselja, u tipu $4-d u b o k a$ starost 26, tipu 5 - vrlo duboka starost pripada najveći broj, čak 98 naselja, tipu 6 - izrazito duboka starost 71 naselje, a tipu 7 - krajnje duboka starost 55 naselja. Proistječe da je gotovo polovina naseljskog skupa za koji je bodovan stupanj ostarjelosti stanovništva zahvaćena najvišim stupnjevima ostarjelosti, odnosno da je stanovništvo tih naselja u stanju izrazito duboke i krajnje duboke starosti. Samo 30 naselja ima nešto bolje bodovne pokazatelje ostarjelosti od ukupne populacije Hrvatske (za koju je $b_{s} 67,0$ ), odnosno stanje je u njima tek nešto manje nepovoljno.

Kakvo je stanje u najvećim otočnim naseljima? Od deset najvećih naselja Mali Lošinj $\left(b_{s}=68,1\right)$ i Hvar $(66,0)$ nalaze se u tipu 4 - duboka starost, dok su ostala u tipu 5 - vrlo duboka starost: Vela Luka $(59,0)$, Blato $(62,0)$, Korčula (63,5), Supetar (63,0), Okrug Gornji $(63,5)$, Vir $(52,0)$, Pag $(56,5)$ i Krk $(62,5)$. Očigledno je da je i stanovništvo velikih naselja (velikih za otočne prilike) zahvaćeno visokim stupnjem ostarjelosti, a to bi stanovništvo trebalo biti nositelj demografskoga i općeg razvoja matičnih otoka. Stanje je slično i u turističkim središtima. Od deset izdvojenih naselja Cres $\left(b_{s}=67,0\right)$ i Novalja $(67,5)$ pripadaju tipu 4 - duboka starost, a ostala tipu 5 - vrlo duboka starost: Bol $(64,5)$, Stari Grad $(58,0)$, Jelsa $(61,4)$, Vis $(57,1)$, Murter $(58,0)$, Rab $(55,5)$, Stara Baška $(50,5)$ i Punat $(60,5)$. Dakle i u toj je skupini visoki stupanj ostarjelosti stanovništva. Očigledno je da turizam, barem onakav kakav smo do sada razvijali, ne može zaustaviti negativne demografske trendove, može ih samo selektivno ublažiti i usporiti. $S$ druge strane, predočeni pokazatelji

10 Skrivena Luka na Lastovu ima 33 stanovnika, a među njima je 12 mladih ( 0 - 19 godina) i 3 stara stanovnika (60 i više godina). Zaklopatica ima 87 stanovnika, 25 je mladih i 10 starih. Oba naselja bilježe porast broja stanovnika u odnosu na 2001.: Skrivena Luka za 15, a Zaklopatica za 16. Istovremeno se u Lastovu, glavnom naselju, smanjio broj stanovnika s 451 na 350. Vjerojatno se dio mlađih stanovnika naselja Lastovo preselio u dva mala naselja smještena u lijepim uvalama. Svakako bi odgovor na pitanje zašto ta lastovska naselja imaju najmanji stupanj ostarjelosti stanovništva (ili najmanje loš dobni sastav) među svim otočnim naseljima, valjalo dokučiti terenskim radom. 
potvrdili su nalaze nekih prijašnjih analiza prema kojima je kod hrvatskih otoka ostarjelost stanovništva glavni ograničavajući čimbenik razvoja novog modela turizma (Nejašmić, 1998; Zupanc, Opačić i Nejašmić, 2001).

Predočeni podaci o stupnju ostarjelosti stanovništva potvrđuju, zajedno s pokazateljima drugih demografskih pojava i procesa, već višekratno utvrđenu činjenicu da je otočno stanovništvo brojčano osiromašeno i strukturno okljaštreno. Mnogi su hrvatski otoci došli u stanje u kojem život polako umire, a stara se ognjišta gase.

\section{DEMOGRAFSKA PERSPEKTIVA OTOČNIH NASELJA}

Predočeno stanje i recentni demografski procesi na hrvatskim jadranskim otocima vrlo su nepovoljni, dio naselja doživio je demografski slom, i sve upućuje na još lošiju perspektivu. Očigledno je da do punog izražaja dolazi demografski momentum (demografska inercija), koji određuje predvidive promjene dobne strukture $\mathrm{u}$ budućnosti. Nastavlja se circulus viciosus depopulacijskih procesa (parcijalnih i ukupnoga) i promjena u dobnom sastavu u smjeru daljnje naglašene senilizacije. To vodi sve nepovoljnijemu demografskom stanju i razvoju otočnog stanovništva.

Sve relevantne projekcije pokazuju jako smanjenje broja stanovnika Hrvatske $\mathrm{u}$ sljedećim desetljećima. ${ }^{11} \mathrm{~S}$ obzirom na predvidljive promjene za ukupnu populaciju, možemo očekivati još pogubnije promjene za njezin demografski najslabiji dio - otočno stanovništvo!

U sljedećih dvadesetak godina stanovništvo svih otočnih naselja prijeći će u višu kategoriju ostarjelosti (tipovi 6 i 7). Valja očekivati da će dvije trećine naseljskog skupa biti zahvaćene najvišim stupnjevima ostarjelosti, odnosno da će njihovo stanovništvo imati obilježje izrazito duboke i krajnje duboke starosti. Naselja koja sada pripadaju tipu 7 - krajnje duboka starost postat će u većini slučajeva »mrtva sela«.

Koliki je skup naselja koja će izumrijeti u doglednoj budućnosti? U pokušaju odgovora polazi se od pretpostavke da će glavni čimbenici starenja i drugih demografskih procesa ostati manje-više isti, odnosno da neće doći do inovacije tipa deux ex machina. U selekcioniranju takvih naselja upotrijebljena su dva demografska parametra:

1. veličina naselja 2011.: sitno naselje, do 99 stanovnika; u takvu skupu do punog izražaja dolazi nepisano pravilo - što je manje naselje, to je veća vjerojatnost da će biti još manje

11 Prema projekciji rađenoj kohortno-komponentnom metodom za zatvorenu populaciju (dakle bez migracije), u Hrvatskoj će 2031. biti 3.680.750 stanovnika; tako će se u trideset godina (2001. polazišna je godina projekcije) broj stanovnika smanjiti za 756.710 ili 17,1\% (Nejašmić i Mišetić, 2004). 
2. udjel (\%) mladoga (0 -19 godina) u ukupnom stanovništvu $10 \%$ i manje (2011.); za graničnu vrijednost uzet je skoro dvostruko manji udjel od onoga za ukupnu otočnu populaciju; za izrazito sitna naselja (s manje od dvadeset stanovnika) dopušteno je lagano odstupanje graničnih vrijednosti. ${ }^{12}$

Naselja bez stalnih stanovnika 2011. nisu ušla u odabrani skup. ${ }^{13}$ Jedan od demografskih kriterija trebao je biti i negativno prirodno kretanje u posljednjemu međupopisnom razdoblju, no u slučaju otočne populacije taj je parametar ispušten jer nema nikakvu selektivnu važnost; sva manja naselja imaju negativno prirodno kretanje od 2001. do 2011.

Temeljem predočenih kriterija izdvojeno je 78 naselja ili $26 \%$ otočnoga naseljskog skupa (prilog 2). Dobiveni je skup više-manje »rastezljiv«; u dodatnoj bi analizi neka naselja mogla ispasti, ali bi druga mogla ući. No, u svakom slučaju, predstavlja jezgru skupine naselja koja će izumrijeti. ${ }^{14} \mathrm{Naj}$ veći je udjel budućih »mrtvih sela « u srednjodalmatinskoj otočnoj skupini $(28,8 \%)$; slijedi kvarnersko otočje $(28,6 \%)$ i sjevernodalmatinsko $(24,4 \%)$, a najmanji je udjel u južnodalmatinskoj skupini $(15,2 \%)$. Pojedinačno, među većim otocima prednjače otok Cres (izumrijet će 73\% naselja), Dugi otok (55\%) i Vis (45\%). Dakle riječ je o vanjskim otocima, na kojima (Cres, Vis) prevladavaju mala naselja smještena u unutrašnjosti otoka. Nadalje, pokazalo se da je razmjerno velik broj otoka čije je jedino naselje ušlo u skup »mrtvih sela«. Takvih je deset od ukupno 26 otoka s jednim naseljem (u kojem je bilo stalnih stanovnika u vrijeme popisa 2011.). Uglavnom je riječ o dvjema skupinama malih otoka: lošinjskoj (od pet otoka s jednim naseljem dva će izumrijeti) i zadarsko-šibenskoj (od petnaest takvih otoka bez stanovnika će ostati njih šest).

Valja ustvrditi da velikom dijelu malih otočnih naselja, osobito na malim, od kopna udaljenim otocima, ali i naseljima u unutrašnjosti većih otoka, prijeti izumiranje. Doći će do gašenja višestoljetnih naseobina kao stalnih ljudskih aglomeracija. Da je to posve moguće, pokazuje i podatak da u naseljima »crne« demografske perspektive živi svega 114 mladih (0 -19 godina), a da čak u 34 naselja nema nijednog mladog stanovnika (2011.).

12 Može se dovesti u pitanje granica udjela mladih, jer i jedan posto mladih znači da naselje neće izumrijeti dok god ti mladi žive. No način života starih sumještana zorno pokazuje što mlade čeka. To će vjerojatno rezultirati odlaskom većine preostale mladeži.

13 Popis 2011. zabilježio je osam »naselja bez stalnih stanovnika«, a to su ona koja praktično i nemaju »demografsku perspektivu«.

14 »Kabinetsko« selektiranje i utvrđivanje naselja koja će izumrijeti ima krupnih nedostataka. Preciznije utvrđivanje ciljanog skupa moguće je postići upotrebom određenih socioekonomskih parametara te, prije svega, terenskim radom, čemu kao podloga mogu poslužiti i predočeni nalazi. 
Neka će buduća »mrtva sela « biti povremeno naseljena tijekom vikenda i turističke sezone, dakle postat će naselja za odmor i rekreaciju. Moguće je da će se negdje javiti i novi oblik naseljenosti - rezidencijalni turizam, pojava kada se imućnija turistička klijentela trajnije nastanjuje na otocima zbog očuvanih prirodnih vrijednosti mora i otočnoga krajobraza (Faričić, 2012). No današnja je stvarnost takva da se u mnogim naseljima postupno gasi gospodarski i društveni život te gubi identitet. U krajoliku prevladavaju znakovi "gašenja ognjišta « - zatvaraju se škole, zapuštaju obradive površine, kuće jedva odolijevaju zubu vremena. To su sela koja u svakom pogledu propadaju, u kojima vene i gasi se oblik života kakav poznajemo. Sadašnji ostarjeli seljaci uglavnom su i njihovi posljednji stanovnici. Glavnina takvih naselja ostat će tek puki geografski pojmovi.

\section{KAKO UBLAŽITI POSLJEDICE DEMOGRAFSKOG STARENJA I USPORITI GA?}

S gledišta dobrobiti pojedinca starenje, tj. produljenje ljudskog vijeka, pobjeda je čovječanstva. No demografsko starenje nedvojbeno je nepovoljan proces koji djeluje na ukupno kretanje stanovništva, općedruštvene prilike i gospodarski razvoj (Stipetić, 1994). O tome H. Mendras piše: »U društvu u kojem je postotak starih ljudi pretjerano velik, očigledno je teško uspostaviti zadovoljavajući i uravnotežen socijalni život. Štoviše, može se smatrati da starenje ima reperkusije na mentalitet, na nivo optimizma i duh poduzetništva stanovništva« (1986: 205-206).

Što se tiče demografskih posljedica, starenje djeluje uglavnom ovako: a) usporava stopu rasta stanovništva, b) smanjuje stopu rodnosti, c) povećava opću stopu smrtnosti, d) smanjuje migraciju stanovništva, e) izaziva daljnje pogoršanje sastava prema dobi i spolu (feminizacija starijih dobnih skupina) i d) utječe na starenje radnoga kontingenta (Wertheimer-Baletić, 1999). Osim demografskih brojne su i društvene, gospodarske, političke i druge posljedice budućih demografskih promjena (Chesnais, 2000). Slijedom čvrste kauzalnosti općerazvojnih i demografskih procesa doći će do umnožavanja negativnih posljedica u gotovo svim područjima društvenog života otočnog stanovništva.

S povećanjem udjela starih ljudi javlja se sve veća potreba za pružanjem raznih oblika neformalne skrbi tom kontingentu stanovništva. Zbog sve manjeg broja djece u obitelji smanjuje se krug glavnih pružatelja skrbi starijima. »Budućim starim ljudima bit će sve teže naći nekoga tko će im pružiti neposrednu skrb, posebice kada je posrijedi svakodnevna emocionalna 
potpora, praktična pomoć u kućanstvu i pružanje različitih oblika njege« (Podgorelec i Klempić, 2007: 129). Izvjesno je da će sve veći broj starih otočana živjeti osamljeno, s rijetkim obiteljskim kontaktima ili bez ikakvih obiteljskih kontakata, čime će biti izloženi društvenoj izolaciji. Sve to zahtijeva prilagođavanje oblika i vrste skrbi za starije. Naime ako se znatno smanjuje broj potencijalnih pružatelja neformalne skrbi, u ispražnjeni će prostor morati u većoj mjeri ući institucionalna zaštita, odnosno organizirana zdravstvena njega i razni oblici socijalne skrbi (Babić, Lajić i Podgorelec, 2004).

Nepovoljne posljedice starenja stanovništva dolaze do punog izražaja u malim naseljima. Stalna erozija generacija, dugotrajno smanjenje fertiliteta i starenje otvaraju niz teško rješivih egzistencijalnih i drugih problema. Opća je tendencija na otocima, kao i u čitavoj Hrvatskoj, da selo u sve većoj mjeri postaje zajednicom staračkih domaćinstava, bez mladih i nasljednika (Magdalenić i Župančić, 1997). Starost postaje teška i osamljena; posebice je depresivno stanje u malim, prometno slabije dostupnim otočnim naseljima.

Što učiniti da se ublaže posljedice demografskog starenja i da se ono uspori? Teorijski, za obnovu biodinamičke snage nužno je u prvi plan staviti pronatalitetnu populacijsku politiku, koja ima dalekosežni učinak na usporavanje starenja stanovništva i uspostavljanje potrebne ravnoteže među dobnim skupinama. No kako to postići u okolnostima suženoga fertilnoga kontingenta i okljaštrenih mladih dobnih skupina u otočnoj populaciji? Beznadan položaj otprilike četvrtine otočnih naselja, kao i visoki stupanj ostarjelosti stanovništva ostalih naselja dokazom su kako su demografska stabilizacija i obnova otoka praktično nemoguće sa snagama in situ.

Stoga se sama po sebi nameće druga mjera za ublažavanje problema starenja - doseljavanje stanovništva, razumije se, prije svega mladoga. Kojeg stanovništva, odakle i kako ga privući na otoke? Hrvatska sve više oskudijeva mladim stanovništvom, dijelom zbog nedostatnog nataliteta, a dijelom zbog odljeva mladih u inozemstvo. Zbog toga se sužava i baza potencijalnih unutarnjih selilaca, a to znači i kontingenta koji bi se eventualno mogao »usmjeriti« na otoke.

Treća je mjera povećanje zaposlenosti mladih otočana radi zaustavljanja njihova odlaska. Vrijeme je pokazalo da sezonska djelatnost poput turizma i skromna otočna poljoprivreda nisu u stanju zadržati mlade na otoku. Nedvojbeno je da za uspješnu organizaciju života na otocima, malim i velikim, nužno treba uspostaviti ravnotežu između potreba i mogućnosti, a činjenica je da u tome postoji trajni nerazmjer, koji je posebice dubok na malim otocima (Šimunović, 2010). Često se u recentnim radovima raspravlja o »održivom razvoju« kao temeljnoj opciji za usporavanje nepovoljnih demo- 
grafskih procesa. Želi se naime pomoću novih razvojnih obrazaca dinamizirati pojedine segmente gospodarskog i društvenog života. Dok se razmišlja kako i čime to postići, »mladi odlaze putem već utabanih selidbenih staza« (Friganović, 2001: 40).

Problem otočja prije svega je problem malih i srednjih otoka koji su udaljeniji od kopna. Veliki otoci bliže su kopnu te raspolažu većim resursima i razvojnim mogućnostima. Iako su i oni demografski ugroženi, na njima živi još uvijek dovoljna kritična masa stanovnika potrebna da bi se organizirao uspješan gospodarski i društveni život. Dakle još uvijek nije kasno. Uz puno uvažavanje posebnosti svakog otoka valja prije svega poboljšati prometnu dostupnost i ukupnu infrastrukturu. Nužno je razvijati polikulturno gospodarstvo koje se temelji na barem jednoj stabilnoj gospodarskoj djelatnosti (Šimunović, 2010). Pritom valja imati na umu da svaki otok ima svoju »mjeru nosivosti« koju treba očuvati u srazu s interesom krupnoga kapitala. Sve to podrazumijeva i donošenje nove politike i novih mjera za razvoj otoka. Valja se usmjeriti na razvojne projekte, iskoristiti europske fondove te privući privatne investitore. U tom će slučaju otoci postati hrvatska razvojna prednost. Do rješenja problema treba doći djelovanjem lokalne i šire zajednice u sinergiji s relevantnim stručnim i znanstvenim ustanovama. Ako se pak ne nađu rješenja ili mjere ne dadu rezultata, ako se otoke prepusti stihiji depopulacije i senilizacije, dio otočja postat će pustoš. To bi s obzirom na vrijednost tog prostora, čije su bogatstvo prije svega ljudi, bio nedopustivi civilizacijski nazadak.

\section{ZAKLJUČAK}

Zaključno možemo ustvrditi da su hrvatski otoci, osim što bilježe jaku depopulaciju u 20. stoljeću, zahvaćeni i odmaklim procesom demografskog starenja. Nepovoljni demografski procesi pak prešli su put od posljedice društvenih zbivanja do važnog čimbenika društvenih i prostornih procesa. Predočena okljaštrenost dobnog sastava, odnosno visoki stupanj ostarjelosti stanovništva, nedvojbeno inducira krupne posljedice. Nepovoljno djeluje na niz društvenih i gospodarskih parametara, a to može rezultirati odlaskom dijela preostale mladeži. Time se produbljuje sociodemografska depresija te ograničava mogućnost stabiliziranja nepovoljnih demografskih i razvojnih tendencija. Iskustva razvijenih govore da nije moguće zaustavljanje depopulacijskih tendencija ako ne dođe do bitne promjene društveno-gospodarskih prilika. Drugim riječima, tek društveno-gospodarski preporod može ublažiti posljedice demografskih procesa, usporiti starenje stanovništva, pa i revitalizirati dio otočnih naselja. 
Ustvrdili smo da će u hrvatskome otočnom prostoru doći do »razrjeđivanja« naseljske strukture, tj. do gašenja četvrtine naseljskog skupa kao aglomeracije stalnih stanovnika. Valja reći da je to dijelom nezaustavljiv proces, odnosno da nema te društvene snage koja može sanirati svako naselje koje izumire. Ta činjenica ujedno pokazuje u kojem smjeru valja djelovati da bi se spriječilo potpuno pražnjenje velikih dijelova otoka ili čitavih otoka. Nužno je naime »locirati« naselja koja imaju razmjerno dobru demografsku osnovicu i neke druge prednosti te im dati razvojne poticaje. Takva naselja, čiju bi »perspektivnost « valjalo sveobuhvatno ocijeniti, postala bi dio nove otočne "naseljske armature s manjim brojem naselja, ali pogodnijima za organiziranije i kvalitetnije življenje. To ne znači da naselja »crne« demografske perspektive valja prepustiti sudbini. Naprotiv, činjenica da je u njima sve više starih i nemoćnih nužno traži veću društvenu skrb za taj kontingent otočnog stanovništva.

Valja upozoriti i na izvjesnu dvojbu glede općeg razvoja hrvatskih otoka u svjetlu sadašnjih i budućih demografskih značajki. Naime pitanje je treba li stanovništvo pratiti razvoj ili obratno, razvoj prilagođavati stanovništvu. Sve je zastupljenije stajalište po kojem nije prihvatljivo forsiranje razvoja znatno iznad potreba otočnog stanovništva. Kada su posrijedi otoci, potrebno je naći ravnotežu koja će poštovati materijalno i duhovno bogatstvo naroda te očuvati temelj na kojem ono počiva.

Otoci su izuzetno vrijedna i vrlo osjetljiva geografska, gospodarska i antropogena sredina. Kada govorimo o hrvatskom otočju, valja istaknuti da je riječ o osebujnom spletu razvojnih značajki, ambijenta i mentaliteta, tj. jedinstvenom skladu prirodnoga i kulturnoga krajolika. U prevladavanju nepovoljnih demografskih tendencija nužan je senzibilan i selektivan pristup. Stoga je u osmišljavanju strategije razvoja prijeko potrebno poštovati posebnosti pojedinih otočnih skupina iotoka. Toj svrsi, vjerujemo, mogu poslužiti i rezultati ove analize.

\section{LITERATURA}

Babić, D., Lajić, I. i Podgorelec, S. (2004). Otoci dviju generacija. Zagreb: Institut za migracije i narodnosti

Božanić, J. (1996). Zakon polisa - Jadranski helieutikon, More, 2 (12): 65-67.

Chesnais, J.-C. (2000). The Inversion of the Age Pyramid and the Future Population Decline in France: Implications and Policy Responses. New York: UN Population Division, Expert Group Meeting on Policy Responses to Population Ageing, http://www.un.org/esa/ population/publications/popdecline/Chesnais.pdf (28. 02. 2011.). 
Defilippis, J. (1997). Dalmatinsko selo u promjenama: dva stoljeća sela i poljoprivrede Dalmacije. Split - Zagreb: Avium - Ministarstvo razvitka i obnove.

Duplančić Leder, T., Ujević, T. i Čala, M. (2004). Coastline lenghts and areas of islands in the Croatian part of the Adriatic Sea determined from the topographic maps at the scale of 1:25 000, Geoadria, 9 (1): 5-32.

Faričić, J. (2012). Geografija sjevernodalmatinskih otoka. Zagreb: Školska knjiga.

Faričić, J. i Magaš, D. (2004). Suvremeni socio-geografski problemi malih hrvatskih otoka - primjer otoka Žirja, Geoadria, 9 (2): 125-158.

Foretić, D. (1969). O ekonomskim prilikama u Dalmaciji u drugoj polovici XIX stoljeća do prvog svjetskog rata, u: Hrvatski narodni preporod u Dalmaciji i Istri: zbornik. Zagreb: Matica hrvatska, 9-45.

Friganović, M. (1962). Suvremeni geografski problemi naših otoka, Geografski horizont, 1-2: 30-41.

Friganović, M. (1980-81). Još o nekim osobitostima kretanja stanovništva općinskih središta i ostalih naselja SR Hrvatske (1948-1981), Radovi (Geografski odjel PMF-a), 15-16: 3-11.

Friganović, M. (1990). Demogeografija: stanovništvo svijeta. 4. izd. Zagreb: Školska knjiga.

Friganović, M. A. (2001). O demografskoj problematici hrvatskih otoka na Jadranu, Sociologija sela, 39 (1-4): 37-39.

Graovac-Matassi, V. (2010). Suvremeni demogeografski razvoj Ista i Škarde, u: J. Faričić (ur.). Otoci Ist i Škarda. Zadar: Sveučilište u Zadru - Zavod za prostorno uređenje zadarske županije - Matica hrvatska, Ogranak - Hrvatsko geografsko društvo Zadar, 431-444.

Klemenčić, M. (1990). Postupak vrednovanja dobnog sastava stanovništva, Radovi (Geografski odjel PMF-a), 25: 73-80.

Lajić, I. (1989). Utjecaj društveno-ekonomskih i demografskih promjena na iseljavanje s dalmatinskih otoka u 19. i prvoj polovini 20. stoljeća, Migracijske teme, 5 (4): 307-324.

Lajić, I. (1992). Stanovništvo dalmatinskih otoka: povijesne i suvremene značajke depopulacije. Zagreb: Consilium - Institut za migracije i narodnosti.

Lajić, I. (1995a). Utjecaj novijeg iseljavanja na demografski razvitak jadranskih otoka, Migracijske teme, 11 (1): 89-116.

Lajić, I. (1995b). Pučanstvo hrvatskih otoka: posljednjih trideset godina, Ceste i mostovi, 41 (3-4): 95-99.

Lajić, I. (2006). Kvarnerski otoci: demografski razvoj i povijesne mijene. Zagreb: Institut za migracije i narodnosti.

Lajić, I. i Nejašmić, I. (1994). Metodološke osobitosti demografskog istraživanja hrvatskog otočja, Društvena istraživanja, 3 (4-5): 381-396.

Lajić, I. i Mišetić, R. (2006). Otočni logaritam-aktualno stanje i suvremeni demografski procesi na jadranskim otocima. Zagreb: Institut za migracije i narodnosti - Ministarstvo mora, turizma, prometa i razvitka.

Magdalenić, I. i Župančić, M. (1997). Socijalno-demografske skice šest područja Republike Hrvatske, Sociologija sela, 35 (1-4): 47-89.

Mendras, H. (1986). Seljačka društva: elementi za jednu teoriju seljaštva. Zagreb: Globus.

Mikačić, V. (1987). Demografska kretanja na jadranskim otocima - suvremeno stanje i perspektive, Pomorski zbornik, 25: 57-73. 
Mišetić, R. (2006). Neka sociodemografska obilježja stanovništva obalnih naselja, Društvena istraživanja, 15 (1-2): 3-26.

Nejašmić, I. (1991a). Depopulacija u Hrvatskoj: korijeni, stanje, izgledi. Zagreb: Globus.

Nejašmić, I. (1991b). Depopulacija istočnojadranskih otoka i izumiranje kao moguća demografska perspektiva, Migracijske teme, 7 (1): 77-99.

Nejašmić, I. (1992). Promjene u dobno-spolnom sastavu stanovništva istočnojadranskog otočja (1953-1999), Acta Geographica Croatica, 27: 15-34.

Nejašmić, I. (1997). Suvremene značajke (bio)reprodukcije stanovništva hrvatskog otočja, Migracijske teme, 13 (1-2): 71-83.

Nejašmić, I. (1998). Croatian Islands: the Role of Demographic Features in Tourism Development, Hrvatski geografski glasnik, 60: 17-30.

Nejašmić, I. (2005). Demogeografija: stanovništvo u prostornim odnosima i procesima. Zagreb: Školska knjiga.

Nejašmić, I. i Mišetić, R. (2004). Buduće kretanje broja stanovnika Hrvatske: projekcija 2001-2031, Društvena istraživanja, 13 (4-5): 751-776.

Nejašmić, I. i Mišetić, R. (2006). Depopulacija otoka Visa, Geoadria, 11 (2): 283-309.

Podgorelec, S. (1998). Utjecaj migracija na starenje stanovništva dalmatinskih otoka, u: I. Lajić (ur.). Migracije u Hrvatskoj: regionalni pristup. Zagreb: Institut za migracije i narodnosti, 137-169.

Podgorelec, S. (2008). Ostarjeti na otoku: kvaliteta života starijeg stanovništva hrvatskih otoka. Zagreb: Institut za migracije i narodnosti.

Podgorelec, S. i Klempić, S. (2007). Starenje i neformalna skrb o starim osobama u Hrvatskoj, Migracijske i etničke teme, 23 (1-2): 111-134.

Royle, S. A. (2001). A Geography of Islands - Small Island Insularity. London - New York: Routledge.

Rubić, I. (1952). Naši otoci na Jadranu. Split: Odbor za proslavu desetgodišnjice Mornarice.

Smoljanović, M., Smoljanović, A. i Nejašmić, I. (1999). Stanovništvo hrvatskih otoka. Split: Zavod za javno zdravstvo Županije splitsko-dalmatinske.

Stiperski, Z., Malić, A. i Kovačević, D. (2001). Međuzavisnost dostupnosti, gospodarstva i revitalizacije hrvatskih otoka, Sociologija sela, 39 (1-4): 153-168.

Stipetić, V. (1994). Ekonomski problemi koje donosi starenje stanovništva, Ekonomija, 1 (1-3): 113-117.

Šimunović, I. (2010). Kamo idu naši otoci?, u: J. Faričić (ur.). Otoci Ist i Škarda. Zadar: Sveučilište u Zadru - Zavod za prostorno uređenje zadarske županije - Matica hrvatska, Ogranak - Hrvatsko geografsko društvo, 17-30.

Wertheimer-Baletić, A. (1979). Demografske značajke jednog otočkog depopulacijskog područja - primjer općine Cres-Lošinj, Ekonomski pregled, 1-2: 35-53.

Wertheimer-Baletić, A. (1999). Stanovništvo i razvoj. Zagreb: Mate.

Wertheimer-Baletić, A. (2009). Starenje stanovništva kao svjetski proces, Rad HAZU, 505: 111-169.

Zupanc, I., Opačić, V. T. i Nejašmić, I. (2001). Utjecaj turizma na demografska kretanja hrvatskih otoka, Acta Geographica Croatica, 35: 133-146. 


\section{IZVORI}

Popis stanovništva 1953., Starost, pismenost $i$ narodnost, knjiga XI, Savezni zavod za statistiku, Beograd, 1960.

Popis stanovništva, kućanstava $i$ stanova 1991., Stanovništvo po spolu i starosti, općinski tablogrami po naseljima, Državni zavod za statistiku, Zagreb, 1992.

Popis stanovništva, kućanstava i stanova 2011., Stanovništvo prema starosti i spolu, Državni zavod za statistiku, Zagreb, http://www.dzs.hr 


\section{PRILOZI}

Prilog 1: Pokazatelji stupnja ostarjelosti stanovništva otočnih naselja 2011.

Appendix 1: Indicators of the degree of population ageing of the island setlements in 2011

\begin{tabular}{|c|}
\hline Naselja $\left(b_{s}\right)$ (ukupno 303 naselja) \\
\hline Tip 1 - na pragu starenja (1 naselje) \\
\hline Skrivena Luka $(97,5)$ \\
\hline Tip 2 - starenje (2 naselja) \\
\hline Sveti Ivan $(85,5)$, Zaklopatica $(87,0)$ \\
\hline Tip 3 - starost (14 naselja) \\
\hline $\begin{array}{l}\text { Uble }(76,5), \text { Saplunara }(76,0) \text {, Nenadići }(75,0) \text {, Vrh }(74,0) \text {, Žgaljići }(82,0) \text {, Hlapa }(73,0) \text {, } \\
\text { Barušići }(82,0) \text {, Milovčići }(79,5) \text {, Zidarići }(79,0) \text {, Cunski }(79,0) \text {, Sveti Jakov }(79,0), \text { Mandre } \\
(73,5), \text { Pražnica }(73,5), \text { Milna (Hvar, } 79,0)\end{array}$ \\
\hline Tip 4 - duboka starost (26 naselja) \\
\hline $\begin{array}{l}\text { Čara }(68,0), \text { Lumbarda }(67,5), \text { Pomena }(68,0) \text {, Cres }(67,0) \text {, Loznati }(67,5) \text {, Bajčići }(70,0) \text {, } \\
\text { Poljica }(71,5) \text {, Batomalj }(69,5) \text {, Bogovići }(69,5) \text {, Oštrobradić }(66,5) \text {, Radići }(67,5) \text {, Sabljići } \\
(65,5) \text {, Sveti Anton }(72,5) \text {, Turčić }(70,0) \text {, Žgombići }(67,0), \text { Omišalj }(70,0) \text {, Mali Lošinj } \\
(68,0) \text {, Mundanije }(68,0) \text {, Caska }(70,0) \text {, Gajac }(67,5) \text {, Novalja }(67,5) \text {, Gorica }(71,0) \text {, } \\
\text { Mrljane }(67,5) \text {, Mastrinka }(72,5) \text {, Hvar }(66,0) \text {, Svirče }(64,5)\end{array}$ \\
\hline
\end{tabular}

Tip 5 - vrlo duboka starost (98 naselja)

Koločep (51,5), Korčula $(63,5)$, Pupnat $(59,0)$, Račišće $(63,5)$, Žrnovo $(64,5)$, Blato $(62,0)$, Smokvica $(59,5)$, Vela Luka $(59,0)$, Pasadur $(52,0)$, Goveđari $(51,0)$, Korita $(63,5)$, Kozarica (59,5), Polače $(61,0)$, Ropa $(62,0)$, Sobra $(61,0)$, Suđurađ $(58,0)$, Šipanska Luka $(53,0)$, Miholašćica $(64,5)$, Valun $(64,0)$, Kornić $(61,0)$, Krk (62,5), Linardići $(52,0)$, Muraj $(60,5)$, Skrbčići $(64,0)$, Jurandvor $(56,7)$, Gabonjin $(59,0)$, Gostinjac $(52,0)$, Klanice $(52,0)$, Klimno (54,5), Polje $(64,5)$, Soline $(51,0)$, Šilo $(53,5)$, Kremenići $(65,0)$, Milčetići $(54,0)$, Porat $(65,0)$, Njivice $(64,5)$, Punat $(60,5)$, Stara Baška $(50,5)$, Garica $(58,5)$, Vrbnik $(59,0)$, Nerezine (65,0), Veli Lošinj $(59,0)$, Banjol $(62,0)$, Barbat na Rabu $(55,0)$, Kampor $(65,0)$, Lopar (64,0),Palit (61,0), Rab (55,5), Supetarska Draga (61,0), Sali $(56,0)$, Kustići $(50,5)$, Metajna (50,5), Kolan (56,0), Košljun $(51,0)$, Miškovići $(58,0)$, Pag $(56,3)$, Šimuni $(64,0)$, Dobropoljana (59,5), Kraj $(62,0)$, Neviđane $(51,0)$, Pašman (51), Tkon $(64,5)$, Kali $(60,5)$, Sutomišćica (50,5), Vir $(52,0)$, Mirca $(65,5)$, Supetar $(63,0)$, Bol $(64,5)$, Murvica $(56,0)$, Milna (Brač, 52,5), Donji Humac $(60,0)$, Nerežišća $(55,2)$, Dol (Brač, 62,0), Postira $(61,5)$, Gornji Humac (56,5), Pučišća $(63,5)$, Novo Selo $(53,5)$, Selca $(52,0)$, Sumartin $(54,0)$, Sutivan (47,5), Arbanija (63,0), Žedno (60,0), Okrug Gornji (63,5), Brusje (57,0), Sveta Nedjelja $(60,0)$, Dol (Hvar, 52,5), Stari Grad $(58,0)$, Jelsa $(61,5)$, Vrisnik $(59,5)$, Zavala $(52,5)$, Krapanj $(50,5)$, Murter $(58,0)$, Betina $(57,5)$, Jezera $(56,5)$, Tisno $(57,0)$, Grohote $(51,5)$, Komiža $(58,0)$, Vis $(57,0)$ 
Naselja $\left(b_{s}\right)$ (ukupno 303 naselja)

Tip 6 - izrazito duboka starost (71 naselje)

Lastovo (44,0), Lopud (49,5), Babino Polje $(47,5)$, Blato (Mljet, 31,5), Prožurska Luka $(42,5)$, Beli $(44,5)$, Martinšćica $(36,0)$, Orlec $(36,5)$, Belej $(46,0)$, Osor $(46,5)$, Punta Križa $(44,5)$, Ustrine $(47,0)$, Ilovik $(45,5)$, Brusići $(45,0)$, Brzac $(39,0)$, Milohnići $(31,0)$, Pinezići $(49,5)$, Baška $(48,0)$, Draga Bašćanska $(41,5)$, Cižići $(40,0)$, Dobrinj $(39,0)$, Kras $(42,0)$, Rasopasno (50,0), Sužan (6), Sv. Ivan Dobrinjski (44,5), Sv. Vid Dobrinjski $(47,5)$, Tribulje $(48,0)$, Županje $(37,0)$, Malinska $(47,5)$, Sv. Vid-Miholjice $(49,5)$, Vantačići $(33,5)$, Susak $(44,5)$, Unije $(38,5)$, Božava $(38,0)$, Luka $(30,5)$, Zaglav $(42,5)$, Žman $(29,5)$, Lun $(49,5)$, Stara Novalja $(42,5)$, Zubovići $(41,0)$, Dinjiška $(44,5)$, Smokvica (Pag, 33,5), Stara Vas (39,0), Vlašići $(45,5)$, Vrčići $(43,0)$, Povljana $(49,0)$, Banj $(47,0)$, Kukljica $(42,5)$, Lukoran $(33,0)$, Poljana $(45,0)$, Preko $(48,5)$, Ugljan $(39,0)$, Splitska $(57,5)$, Škrip $(38,2)$, Ložišća $(38,2)$, Dračevica $(33,0)$, Povlja $(41,0)$, Slatine $(47,0)$, Okrug Donji $(46,3)$, Vrbanj $(48,5)$, Pitve $(44,0)$, Vrboska $(48,5)$, Zastražišće $(37,5)$, Sućuraj 38,5), Prvić Šepurine $(34,0)$, Gornje Selo $(47,0)$, Srednje Selo $(41,2)$, Podhumlje $(32,5)$, Žena Glava $(35,0)$, Dračevo Polje (31,5), Marinje Zemlje $(32,0)$

Tip 7 - krajnje duboka starost (55 naselja)

Potirna (9,5), Maranovići $(21,0)$, Okuklje $(25,0)$, Prožura $(0,0)$, Dragozetići $(5,0)$, Porozina $(8,0)$, Stivan $(25,0)$, Sveti Petar $(27,5)$, Lakmartin $(24,5)$, Risika $(28,2)$, Brbinj $(6,5)$, Dragove $(5,5)$, Savar $(5,5)$, Soline $(0,0)$, Veli Rat $(0,0)$, Verunić $(12,5)$, Ist $(4,5)$, Mali Iž $(13,0)$, Veli Iž $(27,5)$, Brgulje $(2,0)$, Molat $(2,0)$, Zapuntel $(0,0)$, Olib $(13,0)$, Ošljak $(28,5)$, Vidalići $(29,0)$, Bošana $(0,0)$, Ždrelac $(21,0)$, Premuda $(14,0)$, Rava $(5,0)$, Rivanj $(0,0)$, Sestrunj $(7,5)$, Silba $(32,0)$, Vrgada $(30,0)$, Zverinac $(0,0)$, Bobovišća $(15,0)$, Drvenik Mali (3,5), Drvenik Veliki (2,5), Jagodna (30,0), Rudina (28,5), Gdinj $(8,0)$, Ivan Dolac $(29,0)$, Poljica $(26,0)$, Bogomolje $(17,0)$, Kaprije $(19,5)$, Prvić Luka $(22,7)$, Donje Selo (22,5), Maslinica (28,0), Nečujam $(23,6)$, Rogač $(28,5)$, Stomorska $(26,0)$, Milna (Vis, $0,0)$, Podstražje $(22,5)$, Rukavac $(18,5)$, Zlarin $(27,5)$, Žirje $(2,0)$

\section{Naselja s manje od dvadeset stanovnika* (36 naselja)}

Filozići, Grmov, Ivanje, Lubenice, Mali Podol, Merag, Pernat, Predošćica, Vidovići, Vodice, Vrana, Zbičina, Zbišina, Rudine, Žestilac, Ljutići, Maršići, Strilčići, Kampelje, Male Srakane, Vele Srakane, Potočnica, Kolanjski Gajac, Biševo, Velo Grablje, Zaraće, Selca kod Starog Grada, Gromin Dolac, Selca kod Bogomolja, Kornati, Borovik, Duboka, Podšpilje, Plisko Polje, Podselje, Rogačić

* Za naselja s manje od dvadeset stanovnika nije izračunat bodovni pokazatelj ostarjelosti.

Izvor: Popis 2011., izračunao autor 
Prilog 2: Otočna naselja koja će (najvjerojatnije) izumrijeti u doglednoj budućnosti

Appendix 2: Island settlements that will (probably) extinct in the foreseeable future

\begin{tabular}{|c|c|c|c|c|c|c|c|}
\hline $\begin{array}{l}\text { Naselje/ } \\
\text { OTOK }\end{array}$ & $\begin{array}{c}\% \\
(0-19)\end{array}$ & $\begin{array}{l}\text { Broj } \\
\text { stan. } \\
2011 .\end{array}$ & Obilježje & $\begin{array}{l}\text { Naselje/ } \\
\text { OTOK }\end{array}$ & $\begin{array}{c}\% \\
(0-19)\end{array}$ & $\begin{array}{l}\text { Broj } \\
\text { stan. } \\
2011 .\end{array}$ & Obilježje \\
\hline Lakmartin & 8,3 & 24 & $\mathrm{u}$ & \begin{tabular}{|l} 
OŠLJAK \\
$(1 / 1)$
\end{tabular} & 6,9 & 29 & $\mathrm{o}$ \\
\hline Milohnići & 8,0 & 87 & $\mathrm{u}$ & Potočnica & 0,0 & 11 & $\mathrm{u}$ \\
\hline Muraj & 9,5 & 42 & $\mathrm{u}$ & Vidalići & 9,1 & 22 & $\mathrm{o}$ \\
\hline Rudine & 0,0 & 5 & $\mathrm{u}$ & Bošana & 0,0 & 41 & $\mathrm{o}$ \\
\hline $\begin{array}{l}\text { Sv. Ivan } \\
\text { Dobrinjski }\end{array}$ & 6,4 & 47 & $\mathrm{u}$ & $\begin{array}{l}\text { Kolanjski } \\
\text { Gajac }\end{array}$ & 5,9 & 17 & $\mathrm{u}$ \\
\hline Tribulje & 9,3 & 54 & $\mathrm{u}$ & PAG (4/25) & & & \\
\hline Žestilac & 0,0 & 9 & $\mathrm{u}$ & \begin{tabular}{|l|l} 
KORNAT \\
$(1 / 1)$
\end{tabular} & 5,3 & 19 & o \\
\hline Ljutići & 0,0 & 9 & $\mathrm{u}$ & $\begin{array}{l}\text { DRVENIK } \\
\text { M. }(1 / 1)\end{array}$ & 0,0 & 87 & o \\
\hline Maršići & 10,0 & 10 & $\mathrm{u}$ & Dračevica & 9,0 & 89 & $\mathrm{u}$ \\
\hline Strilčići & 0,0 & 3 & $\mathrm{u}$ & BRAČ (1/22) & & & \\
\hline Kampelje & 12,5 & 8 & $\mathrm{u}$ & Velo Grablje & 0,0 & 7 & $\mathrm{u}$ \\
\hline KRK $(11 / 68)^{*}$ & & & & Zaraće & 14,3 & 14 & $\mathrm{O}$ \\
\hline Dragozetići & 0,0 & 20 & $\mathrm{u}$ & Rudina & 8,6 & 70 & $\mathrm{u}$ \\
\hline Filozići & 16,7 & 6 & $\mathrm{u}$ & $\begin{array}{l}\text { Selca kod } \\
\text { Starog Grada }\end{array}$ & 11,8 & 17 & $\mathrm{u}$ \\
\hline Grmov & 0,0 & 2 & $\mathrm{u}$ & $\begin{array}{l}\text { Gromin } \\
\text { Dolac }\end{array}$ & 0,0 & 3 & $\mathrm{o}$ \\
\hline Ivanje & 0,0 & 3 & $\mathrm{u}$ & Ivan Dolac & 0,0 & 39 & $\mathrm{o}$ \\
\hline Lubenice & 0,0 & 12 & $\mathrm{u}$ & Poljica & 10,2 & 59 & $\mathrm{u}$ \\
\hline Mali Podol & 0,0 & 3 & $\mathrm{u}$ & $\begin{array}{l}\text { Selca kod } \\
\text { Bogomolja }\end{array}$ & 0,0 & 6 & $\mathrm{u}$ \\
\hline Merag & 10,0 & 10 & $\mathrm{o}$ & HVAR (8/28) & & & \\
\hline Pernat & 0,0 & 8 & $\mathrm{u}$ & Borovik & 8,3 & 12 & $\mathrm{u}$ \\
\hline Porozina & 0,0 & 29 & $\mathrm{O}$ & Duboka & 7,7 & 13 & $\mathrm{u}$ \\
\hline Predošćica & 0,0 & 3 & $\mathrm{u}$ & Podšpilje & 0,0 & 11 & $\mathrm{u}$ \\
\hline Stivan & 7,5 & 40 & $\mathrm{u}$ & Žena Glava & 8,7 & 46 & $\mathrm{u}$ \\
\hline Sveti Petar & 14,3 & 14 & $\mathrm{u}$ & \begin{tabular}{|l} 
Dračevo \\
Polje
\end{tabular} & 7,7 & 13 & $\mathrm{u}$ \\
\hline
\end{tabular}




\begin{tabular}{|c|c|c|c|c|c|c|c|}
\hline $\begin{array}{l}\text { Naselje/ } \\
\text { OTOK }\end{array}$ & $\begin{array}{c}\% \\
(0-19)\end{array}$ & $\begin{array}{l}\text { Broj } \\
\text { stan. } \\
2011 .\end{array}$ & Obilježje $\mathrm{e}^{* *}$ & $\begin{array}{l}\text { Naselje/ } \\
\text { OTOK }\end{array}$ & $\begin{array}{c}\% \\
(0-19)\end{array}$ & $\begin{array}{l}\text { Broj } \\
\text { stan. } \\
2011 .\end{array}$ & Obilježje \\
\hline Vidovići & 0,0 & 2 & $\mathrm{u}$ & $\begin{array}{l}\text { Marinje } \\
\text { Zemlje }\end{array}$ & 9,5 & 63 & $\mathrm{u}$ \\
\hline Vodice & 0,0 & 7 & $\mathrm{u}$ & Milna & 0,0 & 30 & $\mathrm{o}$ \\
\hline Vrana & 16,7 & 12 & $\mathrm{u}$ & Plisko Polje & 0,0 & 19 & $\mathrm{u}$ \\
\hline Zbičina & 0,0 & 5 & $\mathrm{u}$ & Podselje & 10,5 & 19 & $\mathrm{u}$ \\
\hline Zbišina & 0,0 & 2 & $\mathrm{u}$ & Podstražje & 7,5 & 40 & $\mathrm{u}$ \\
\hline Osor & 6,7 & 60 & o & Rogačić & 0,0 & 12 & $\mathrm{o}$ \\
\hline Punta Križa & 7,9 & 63 & $\mathrm{u}$ & Rukavac & 4,5 & 66 & $\mathrm{o}$ \\
\hline CRES (19/26) & & & & VIS (12/16) & & & \\
\hline $\begin{array}{l}\text { M. } \\
\text { SRAKANE } \\
(1 / 1)\end{array}$ & 0,0 & 2 & $\mathrm{o}$ & $\begin{array}{l}\text { BIŠEVO } \\
(1 / 1)\end{array}$ & 0,0 & 15 & $\mathrm{u}$ \\
\hline $\begin{array}{l}\text { V. SRAKANE } \\
(1 / 1)\end{array}$ & 0,0 & 3 & o & Potirna & 4,3 & 23 & $\mathrm{u}$ \\
\hline $\begin{array}{l}\text { PREMUDA } \\
(1 / 1)\end{array}$ & 6,3 & 64 & $\mathrm{u}$ & $\begin{array}{l}\text { KORČULA } \\
(1 / 10)\end{array}$ & & & \\
\hline Brgulje & 2,1 & 48 & $\mathrm{u}$ & Blato & 5,1 & 39 & $\mathrm{u}$ \\
\hline Zapuntel & 0,0 & 42 & $\mathrm{u}$ & Maranovići & 4,7 & 43 & $\mathrm{u}$ \\
\hline MOLAT (2/3) & & & & Okuklje & 6,5 & 31 & $\mathrm{o}$ \\
\hline RIVANJ (1/1) & 0,0 & 31 & $\mathrm{o}$ & Prožura & 0,0 & 40 & $\mathrm{u}$ \\
\hline $\begin{array}{l}\text { SESTRUNJ } \\
(1 / 1)\end{array}$ & 4,2 & 48 & $\mathrm{u}$ & \multicolumn{4}{|l|}{ MLJET (4/14) } \\
\hline $\begin{array}{l}\text { ZVERINAC } \\
(1 / 1)\end{array}$ & 0,0 & 43 & o & \multirow{2}{*}{\multicolumn{3}{|c|}{ OTOČJE - ukupno (78/303) }} & \\
\hline Brbinj & 2,6 & 76 & $\mathrm{o}$ & & & & \\
\hline Dragove & 5,6 & 36 & $\mathrm{u}$ & & & & \\
\hline Savar & 5,7 & 53 & o & & & & \\
\hline Soline & 0,0 & 38 & $\mathrm{o}$ & & & & \\
\hline Veli Rat & 0,0 & 60 & o & & & & \\
\hline Verunić & 5,0 & 40 & o & & & & \\
\hline $\begin{array}{l}\text { DUGI OTOK } \\
(6 / 11)\end{array}$ & & & & & & & \\
\hline
\end{tabular}

* U zagradi je broj naselja »crne« perspektive $u$

odnosu na ukupni broj naselja otoka.

** $u=$ naselje u unutrašnjosti otoka

$o=$ naselje na obali

Izvor: Popis 2011. 


\title{
Demographic Ageing on Croatian Islands
}

\author{
Ivo Nejašmić
}

\author{
SUMMARY
}

This paper analyses the changes in the population structure of the Croatian islands by age, warns of the degree of ageing, provides spatial differentiation of this process and presents perspective of ageing at the level of settlement. Typing of population ageing is based on scores and has seven types. The total island population in 2011 belongs to the type 5 - very old population. Almost a half of the settlements (out of 303) have been affected by the highest levels of ageing (types 6 and 7). It was found that a quarter of island settlements will become "dead villages" in a foreseeable future; most of them are on small islands but also in the interior of larger islands. These are villages decaying in every respect, in which the way of life, as we know it, veins and goes out. The present ageing villagers are their last residents in most cases. Everything suggests that demographic recovery of the islands is not possible with the forces in situ. It is important to strike a balance between the needs and opportunities in order to successfully organize life on the islands, both small and large ones, and the fact is that there is a continuing disparity, which is especially profound in small islands. A sensitive and selective approach is needed to overcome the unfavourable demographic trends. Therefore it is necessary to respect the particularities of individual islands and island groups in devising development strategy. Solutions to the problems must come of the local and wider community in synergy with relevant professional and scientific institutions. However, if the solutions are not found or measures do not give results, if the islands are left to desorganisation and senilisation, a part of the islands will become a wasteland. With regard to the value of this area whose wealth are people in the first place, this would be an intolerable civilization decline.

KEY WORDS: Croatian islands, population ageing, demographic perspective, effects of ageing 